\title{
Intensitas Penyakit pada Tanaman Ciplukan (Physalis angulata L.) yang Diberikan Kombinasi Perlakuan Pupuk Hayati (Mikoriza) dan Organik
}

\section{Diseases Intensity of Ciplukan Plants (Physalis angulata L.) Treated with Biological (Mycorrhiza) and Organic Fertilizer}

\author{
Ratna Dwi Hirma Windriyati ${ }^{1}$, Ari Kurniawati ${ }^{2}$, Nur Kholida Wulansari ${ }^{3}$ \\ 1,2,3 Tenaga Pendidik Program Studi Agroteknologi, Fakultas Sains dan Teknologi, Universitas Nahdlatul Ulama \\ Purwokerto J1.Sultan Agung No.42 Karangklesem Purwokerto, Jawa Tengah, 53144 \\ ${ }^{2}$ Festetic Doctoral School, Georgikon Faculty, Szent Istvan University, Hungary 8360 \\ rdh.windriyati@gmail.com
}

Article Submitted : 09-11-2021

Article Accepted : 27-12-2021

\begin{abstract}
Ciplukan plant is a plant that has potential to be used as a medicinal plant because it has various bioactive contents. Several studies that have been carried out are still limited to the potential, content and benefits of ciplukan plants. The aspect of disease attack on ciplukan plants, there has not been much research, even though this plant has various benefits and is currently being developed. This is what underlies this research. If previous research used organic and chemical fertilizers, it is also necessary to compare using biological fertilizers derived from mycorrhizal fungi against diseases found in ciplukan plants. The stages of the research carried out were planting preparation and application, observation, maintenance and data analysis. The aim of research was to determine the types and symptoms of disease, as well as important diseases-causing pathogens in ciplukan plants and the effect of a combination of biological (mycorrhizal) and organic fertilizers on diseases intensity. The results of the research obtained two types of diseases that occurred in ciplukan plants, namely leaf spot symptoms caused by Cercospora sp. and curly leaf symptoms caused by Cucumber Mosaic Virus (CMV). The combination of mycorrhizal treatment and organic fertilizer (manure) tends to increase the intensity of leaf spot disease and the incidence of curly leaf diseases.
\end{abstract}

Keywords: Physalis angulata L., Plant Diseases, Mycorrhiza, Organic Fertilizer

\section{PENDAHULUAN}

Tanaman ciplukan atau ceplukan merupakan salah satu tanaman yang berpotensi untuk dijadikan tanaman obat karena memiliki berbagai kandungan bioaktif, seperti flavonoid, alkaloid, saponin, steroid, dan beberapa senyawa lainnya. Tanaman ciplukan memiliki nama ilmiah Physalis angulata L. yang berasal dari benua Amerika. Tanaman ini bersifat invasif dan terkadang dianggap gulma karena sering tumbuh di sekitar tanaman budidaya. Menurut Travlos (2012), ciplukan dapat bertahan hidup di lingkungan dengan tingkat kelembaban tanah yang cukup rendah, sehingga sangat cocok dibudidayakan di negara-negara tropis, seperti Indonesia yang terkadang memiliki curah hujan yang cukup rendah di musim kemarau. Selain itu, ciplukan juga dapat tumbuh di lahan-lahan marjinal di Indonesia, seperti tanah gambut yang memiliki tingkat kejenuhan basa dan tingkat kesuburan tanah yang rendah, bereaksi masam, dan banyak senyawa toksik (Nurvitha, 2016; Sasli dan Wicaksono, 2017).

Peluang dan potensi tanaman ciplukan masih belum terinformasikan secara menyeluruh kepada masyarakat luas, sehingga pemanfaatannya pun masih sangat terbatas. Bahkan masih ada masyarakat yang menganggap tanaman ini sebagai gulma yang harus dimusnahkan. Hal ini sangat disayangkan mengingat manfaatnya yang cukup banyak. Jika dibiarkan terus-menerus, ketidaktahuan ini justru akan menyebabkan semakin langkanya tanaman ciplukan di sekitar kita. Padahal, dilihat dari aspek budidayanya yang relatif mudah dengan segudang manfaatnya, tanaman ciplukan ini sangat prospektif untuk dikembangkan secara komersil.

Beberapa penelitian yang telah banyak dilakukan masih sebatas potensi, kandungan, dan manfaat tanaman ciplukan, seperti penelitian yang telah dilakukan oleh (Rengifoo dan Vargas (2013) mengenai penggunaan ciplukan sebagai obat tradisional, (Januário dkk., 2002; Guimarães dkk., 2009; Osho dkk., 2010) yang membahas mengenai aktivitas senyawa physalin pada tanaman ciplukan sebagai antimikobakterial dan antitumor.

Pengembangan dari aspek budidayanya masih terus dilakukan untuk mendapatkan Good Agricultural Practies (GAP) agar dapat dibudidayakan secara kontinu dan komersil, mulai dari aspek pemupukan dan pengendalian hama penyakit pada tanaman ciplukan. Menurut Ariati dkk. (2017), pemupukan organik pada tanaman ciplukan memberikan hasil yang baik, baik dari sisi agronomi maupun kandungan biokimianya jika dibandingan dengan penggunaan pupuk kimia. Lebih lanjut (Nurvitha, 2016) juga menjelaskan bahwa pemberian berbagai jenis pupuk kandang, 
seperti pupuk kandang sapi, kambing, dan ayam memberikan pengaruh yang nyata terhadap pertumbuhan dan hasil tanaman ciplukan. Aspek serangan patogen pada tanaman ciplukan belum banyak diteliti, padahal tanaman yang sehat juga akan mendukung pertumbuhan dan hasil yang baik pula. Oleh karena itu, penelitian bertujuan untuk mengetahui penyakit yang terdapat pada tanaman ciplukan serta gejala penyakit dan intensitas penyakit pada tanaman ciplukan.

\section{BAHAN DAN METODE}

Penelitian dilaksanakan di kebun percobaan UNU Purwokerto yang terletak di Desa Teluk Kecamatan Purwokerto Selatan dan Laboratorium IPA Terpadu UNU Purwokerto, pada bulan JuliOktober 2020.

Bahan yang digunakan adalah benih tanaman ciplukan, pupuk kandang kambing murni, pupuk hayati (mikoriza) berisi Gigaspora sp., Glomus sp. dan Acaulospora sp. (kerapatan spora per 10 gram sekitar 400 spora) diperoleh dari Balai Pengkajian Bioteknologi BPPT.

Alat yang digunakan adalah polibag ukuran 30x40, cangkul, gembor (pot siram), ember, sprayer, timbangan, penggaris, meteran, jangka sorong, cawan petri, jarum ose, tabung Erlenmeyer, gelas benda, penutup kaca, autoklaf, mikroskop, kamera, kertas label dan alat tulis.

Penelitian menggunakan Rancangan Acak Kelompok Lengkap (RAKL) dengan dua faktor yaitu faktor pertama mikoriza (M), taraf M0 (tanpa mikoriza), M1 (10 gram/tanaman), M2 (20 gram/tanaman), M3 (30 gram/tanaman), faktor kedua pupuk organik (P), taraf P0 (tanpa pupuk organik), P1 (10 gram/tanaman), P2 (20 gram/tanaman), P3 (30 gram/tanaman), sehingga terdapat 16 kombinasi perlakuan. Setiap perlakuan diulang sebanyak 6 kali dengan masing-masing unit terdiri dari satu tanaman, sehingga total percobaan adalah $4 \times 4 \times 6=96$ polibag.

Penanaman dilakukan dengan sistem tabela atau tanam benih langsung bersamaan dengan aplikasi perlakuan. Kemudian, setelah 3 MST, bibit dijarangkan dan hanya disisakan 1 tanaman per polibag. Perawatan tanaman rutin yang dilakukan adalah penyiangan rumput dan penyiraman. Buah dipanen ketika tanaman memasuki umur 8 MST. Pemanenan dilakukan secara bertahap sampai tanaman berumur 12 MST. Pengamatan yang dilakukan, meliputi gejala penyakit pada tanaman ciplukan, intensitas penyakit dan derajat infeksi mikoriza. Penilaian intensitas penyakit menggunakan rumus (Fitriani dkk., 2019):

Keterangan:

$$
\mathrm{IP}=\frac{\sum(\mathrm{n} \mathrm{x} \mathrm{v})}{\mathrm{N} \mathrm{x} \mathrm{Z}} \times 100 \%
$$

IP : intensitas penyakit (\%)

$\mathrm{n} \quad$ : jumlah daun dari tiap kategori serangan

$\mathrm{v} \quad$ : nilai skala dari tiap kategori serangan
$\mathrm{N} \quad$ : jumlah daun yang diamati

$\mathrm{Z} \quad$ : nilai kategori serangan tertinggi

Persentase infeksi mikoriza dihitung dengan rumus (Fitriani dkk., 2019):

Persentase infeksi $=\frac{\sum \text { bagian tanaman yang terkoloni }}{\sum \text { bagian tanaman yang diamati }} \times 100 \%$

Data selanjutnya dianalisis menggunakan ANOVA (Analysis Of Variance) dan diuji lanjut dengan uji DMRT (Duncan Multiple Range Test) dengan tingkat kepercayaan $5 \%$.

\section{HASIL DAN PEMBAHASAN}

Terdapat dua gejala penyakit yang ditemukan pada tanaman ciplukan dalam penelitian ini yaitu bercak daun dan keriting daun. Berikut ini merupakan penampakan gejala penyakit tersebut.

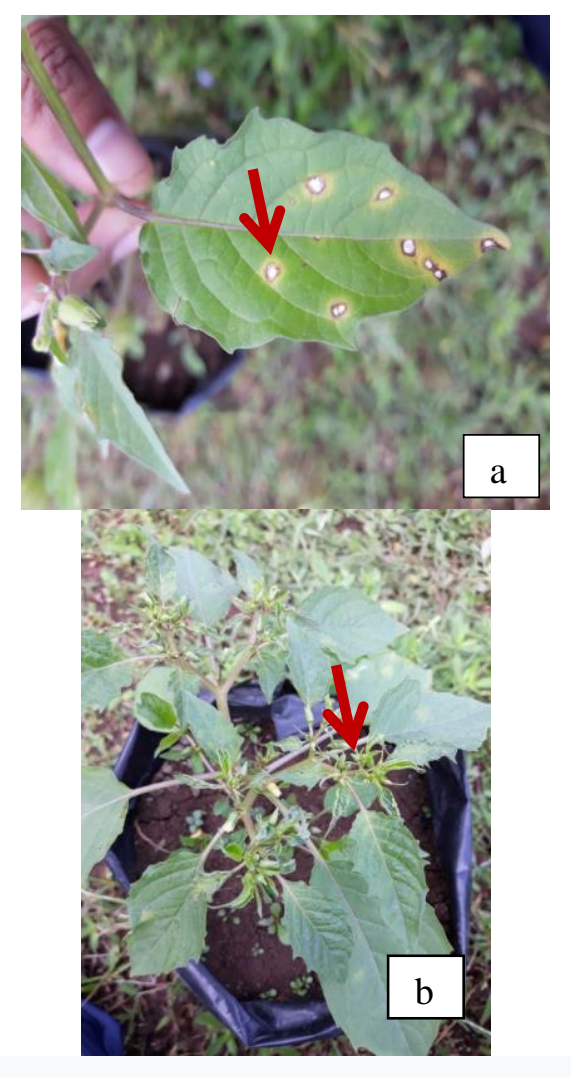

Gambar 1. (a) Gejala bercak daun dan (b) keriting daun

Gejala bercak daun ditandai dengan adanya bercak bulat berwarna putih dengan tepi berwarna cokelat kekuningan. Bercak daun dapat membesar dan ketika bercak sudah tua cenderung berwarna kecoklatan dan kering. Bercak akan jatuh dan menyebabkan daun berlubang. Daun yang bergejala bercak akan rontok meskipun daun belum sepenuhnya menguning. Berdasarkan hasil pengamatan mikroskopis yang dilakukan dapat terlihat adanya hifa bersekat, bercabang, berwarna hialin agak gelap dan konidiofor menempel pada stroma. Ketika ditumbuhkan pada media PDA, hifa berwarna putih kekuningan dan semakin tua umurnya miselum akan berubah warna menjadi 
agak kecokelatan. Miselium tumbuh ke samping dan ke atas.

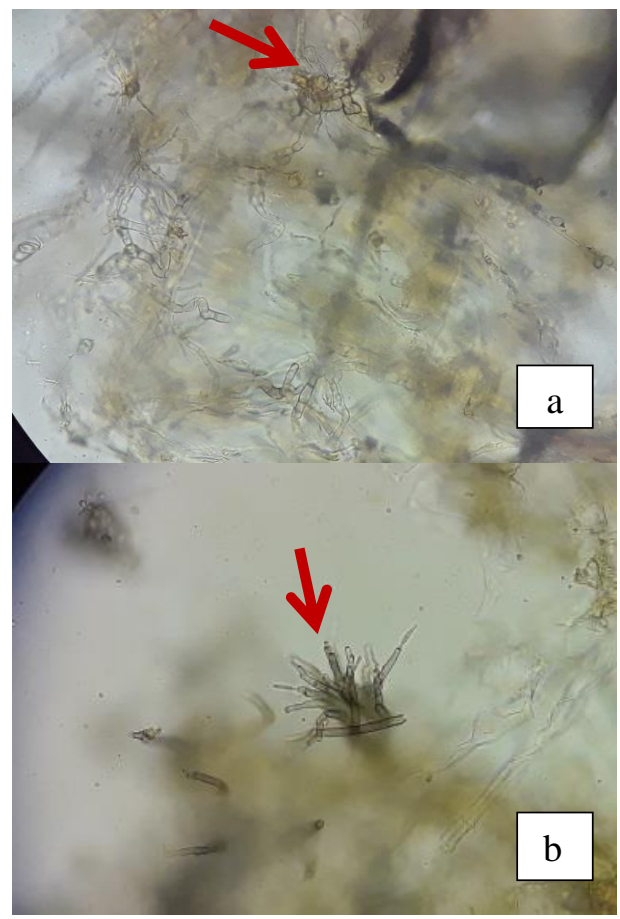

Gambar 2. Mikroskopis Cercospora sp. pada daun ciplukan (a) stromata dan (b) konidiofor

(Phengsintham, 2013) menyatakan jamur Cercospora physalidis yang menginfeksi tanaman ciplukan mempunyai gejala berupa bercak daun melingkar atau suborbikuler dengan diameter 1-10 $\mathrm{mm}$, berwarna coklat keabu-abuan di bagian tengah dan coklat gelap di bagian tepi luarnya. Miselium hifa bercabang dengan lebar 3-6 $\mu \mathrm{m}$, bersekat dengan jarak antar sekat 6-14 $\mu \mathrm{m}$, hialin agak kecoklatan atau kehijauan, lebar dinding 0.25-0.8 $\mu \mathrm{m}$, halus dan membentuk hifa stromatis. Stromata berkembang baik, bentuk oval hingga elip, diameter 15-32 $\mu \mathrm{m}$. Konidiofor keluar dari stomata, tidak bercabang, lurus hingga melengkung, silindris, jarak antar septa 7-35 $\mu \mathrm{m}$. Inang jamur patogen ini antara lain Physalis alkekengi L., P. angulata L., $P$. franchetii Mast., $P$. heterophylla Nees, $P$. hybrida Vilm., P. lanceolata Michx., P. lobata Torr., $P$. longifolia Nutt., P. minima L., P. viscosa L., Physalis sp. (Solanaceae).

Gejala keriting daun mulai terlihat di lahan penelitian pada saat tanaman berumur empat minggu setelah tanam. Gejala dimulai dari bagian pucuk atau titik tumbuh, daun muda mengalami malformasi yaitu daun menggulung atau keriting. Tanaman dengan gejala yang parah seluruh daunnya keriting dan pada saat masa generatif menyebabkan buah ciplukan yang dihasilkan berukuran lebih kecil dan bentuknya keriput. Berdasarkan hasil pengujian serologi (Elisa langsung) yang dilakukan di Balai Penelitian Tanaman Hias (Balithi) menggunakan anti serum spesifik Cucumber Mozaik Virus (CMV) dan Tobacco Mozaic Virus (TMV). Ukur intensitas perubahan warna (kandungan virus) dengan menggunakan Elisa reader pada panjang gelombang $405 \mathrm{~nm}$. Sampel dikatakan positif mengandung virus CMV maupun TMV apabila nilai absorban sama dengan tiga kali absorban kontrol negatif, atau lebih tinggi dari tiga kali absorban kontrol negatif.

Tabel 1. Hasil Uji Serologi

\begin{tabular}{ccc}
\hline \multirow{2}{*}{ Sampel Tanaman } & \multicolumn{2}{c}{ Antiserum spesifik } \\
\cline { 2 - 3 } & CMV & TMV \\
\hline 1 & + & - \\
\hline 2 & + & - \\
\hline 3 & + & - \\
\hline 4 & - & - \\
\hline 5 & + & - \\
\hline Kontrol + & + & + \\
\hline Kontrol - & - & - \\
\hline
\end{tabular}

\section{Keterangan:}

+ (reaksi positif terhadap antiserum spesifik )

- (reaksi negatif terhadap antiserum spesifik)

Sampel tanaman yang diuji diambil lima tanaman bergejala keriting secara acak. Pengujian menggunakan anti serum spesifik TMV menunjukkan semua sampel hasilnya negatif, sedangkan dengan anti serum spesifik CMV menunjukkan empat sampel hasilnya positif dan satu sampel hasilnya negatif. CMV merupakan virus dari genus Cucumovirus, famili Bromoviridae, yang dapat menginfeksi lebih dari 100 famili tanaman sayuran dan hortikultura (Mochizuki dan Ohki, 2012). Beberapa tanaman yang diketahui menjadi inang CMV seperti mentimun, cabai besar, cabai rawit, tomat, pare dan labu (Pandawani dan Hanum, 2016). Penularan keriting daun di lahan penelitian kemungkinan terjadi karena adanya inang utama virus CMV yaitu mentimun dan melon yang ditanam petani di sekitar lahan dan juga banyaknya vektor virus.

Penelitian yang dilakukan Park, Choi dan Hong (2016) menunjukan bahwa CMV menyebabkan tanaman Physalis angulata bergejala mosaik pada daun bagian atas. Sastry, dkk. (2019) juga melaporkan infeksi CMV pada tanaman Physalis minima menunjukkan gejala bintik mosaik. Akan tetapi, gejala penyakit ciplukan dalam penelitian ini hanya didominasi dengan gejala keriting, sedangkan gejala lain seperti mosaik sangat sedikit.

Menurut Pandawani dan Hanum (2016), gejala penyakit yang disebabkan CMV bermacammacam, bergantung pada jenis tanaman dan umur tanaman. Virus ini dapat ditularkan oleh vektor kutu secara nonpersisten dan juga melalui inokulasi getah mekanis. Gejala yang terjadi tanaman mentimun mozaik, klorosis, kerdil, daun malformasi dan nekrosis sistemik. Gejala pada cabai berupa mozaik, pada tomat berupa mozaik dan malformasi, sedangkan pada terong, kacang 
panjang dan buncis tidak menimbulkan gejala setelah diinokulasi virus.

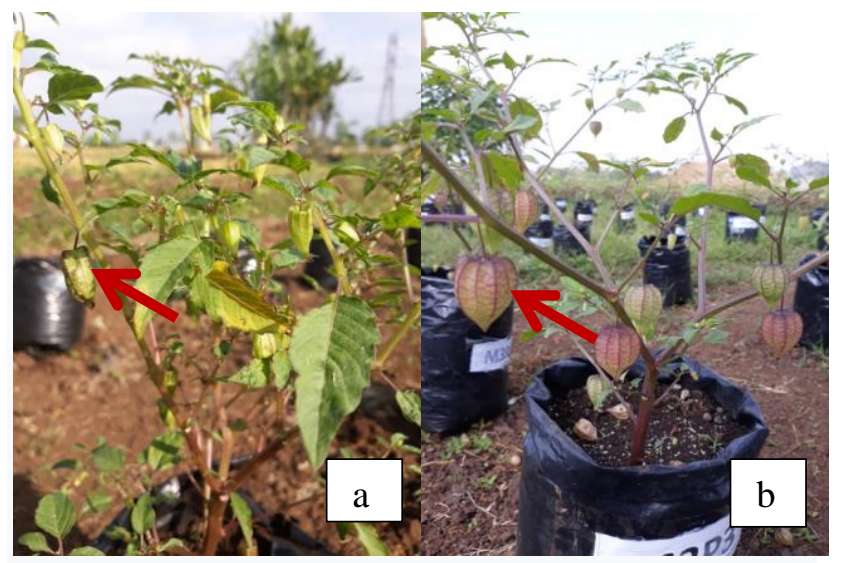

Gambar 3. Buah ciplukan pada tanaman terinfeksi CMV (a) dan (b) tidak terinfeksi CMV

\section{Pengaruh Mikoriza dan Pupuk Organik (Kotoran Kambing) secara Mandiri}

Berdasarkan hasil Tabel 2, inokulasi mikoriza secara mandiri (M1, M2, dan M3) berpengaruh nyata terhadap intensitas penyakit bercak daun dan keriting daun pada tanaman ciplukan. Namun, pengaruh mikoriza pada tanaman ciplukan justru meningkatkan intensitas penyakit bercak daun dan kejadian penyakit keriting daun dibandingkan tanpa pemberian mikoriza. Hal ini diduga karena kandungan $\mathrm{P}$ tersedia pada tanah sudah tinggi sehingga menyebabkan pertumbuhan mikoriza tidak optimal dan peranannya menjadi tidak penting. Oleh karena itu penambahan mikoriza pada $\mathrm{pH}$ tanah tinggi menyebabkan simbiosis antara tanaman dan mikoriza tidak menguntungkan (Oktaviana dan Harso, 2019).

Tabel 2. Pengaruh mikoriza dan pupuk kandang kambing secara mandiri terhadap penyakit bercak daun dan keriting daun

\begin{tabular}{ccc}
\hline & \multicolumn{2}{c}{ Variabel pengamatan } \\
\cline { 2 - 3 } Perlakuan & $\begin{array}{c}\text { Intensitas } \\
\text { penyakit } \\
\text { Bercak daun }\end{array}$ & $\begin{array}{c}\text { Kejadian } \\
\text { penyakit } \\
\text { Keriting daun }\end{array}$ \\
\hline Mikoriza & $18.61 \mathrm{ab}$ & $15.38 \mathrm{~b}$ \\
\hline M0 & $16.81 \mathrm{~b}$ & $25.31 \mathrm{a}$ \\
\hline M1 & $19.31 \mathrm{a}$ & $27.60 \mathrm{a}$ \\
\hline M2 & $18.75 \mathrm{a}$ & $16.60 \mathrm{a}$ \\
\hline M3 & $*$ & $* *$ \\
\hline Pupuk organik & 18.61 & $21.03 \mathrm{~b}$ \\
\hline P0 & 19.03 & $18.64 \mathrm{~b}$ \\
\hline P1 & 17.78 & $23.97 \mathrm{a}$ \\
\hline P2 & 18.06 & $21.24 \mathrm{~b}$ \\
\hline P3 & tn
\end{tabular}

Keterangan: Angka yang diikuti huruf yang sama pada kolom yang sama, tidak berbeda nyata pada Uji Rentang Ganda Duncan (DMRT) taraf 5\%

Penelitian yang dilakukan oleh Sariasih, dkk. (2012) menunjukan bahwa pemberian mikoriza tidak mampu menekan penyakit bercak daun pada tanaman kakao, yang ditandai dengan tidak adanya senyawa asam salisilat yang terbentuk pada tanaman yang diinokulasi mikoriza. Asam salisilat ini merupakan senyawa yang dibentuk tanaman ketika terjadi infeksi untuk mengaktifkan gen ketahanan tanaman untuk melawan serangan patogen.

Pemberian pupuk organik secara mandiri ( $\mathrm{P} 1$, P2 dan P3) tidak memberikan pengaruh nyata pada intensitas penyakit bercak daun, jika dibandingkan dengan tanpa pemberian pupuk kandang (P0). Sedangkan pada keriting daun, pemberian pupuk kandang cenderung meningkatkan kejadian penyakit. Hal ini diduga karena sudah tingginya $\mathrm{P}$ tersedia pada tanah sehingga pemberian pupuk kandang kambing tidak begitu bermanfaat untuk tanaman.

Perlakuan kombinasi dosis mikoriza dan pupuk organik (kandang kambing) berpengaruh nyata pada penyakit bercak daun dan keriting daun, tetapi tidak berpengaruh nyata terhadap infeksi mikoriza pada perakaran ciplukan (Tabel 3). Namun, intensitas penyakit bercak daun pada perlakuan M0P0 tidak jauh berbeda dengan perlakuan M1P1, M2P0, M2P3 dan juga M3P0 bahkan cenderung meningkat. Hal serupa juga terjadi pada kejadian penyakit keriting daun. Perlakuan M0P0 menunjukan nilai yang rendah dibandingkan dosis M1P0, M2P0 dan M3P0. Pemberian mikoriza dan pupuk menyebabkan peningkatan kejadian penyakit pada tanaman ciplukan.

Menurut Hernandez, dkk (2020), kadar P dalam tanah menentukan pengaruh mikoriza terhadap tanaman. Balzergue, dkk. (2013) menyatakan bahwa mikoriza akan lebih efektif jika diberikan pada tanah yang kandungan $\mathrm{P}$ tersedianya rendah. Kandungan $\mathrm{P}$ yang rendah pada akar tanaman akan meningkatkan kandungan karbohidrat di dalam akar sehingga respon mikoriza terhadap tanaman akan lebih baik.

Menurut Pulungan (2015), Qin, dkk (2020), Ishak, dkk. (2021), pemberian inokulum mikoriza pada tanah dengan kandungan $\mathrm{P}$ tinggi dapat menyebabkan simbiosis tidak menguntungkan karena mikoriza tidak membantu penyerapan unsur hara, sedangkan tanaman tetap menyuplai makanan (karbohidrat) untuk mikoriza. Hal ini dikarenakan mikoriza dapat dikatakan sebagai parasit jika jumlah karbohidrat yang dikeluarkan tanaman lebih besar daripada yang diperoleh tanaman dari mikoriza. 
Tabel 3. Pengaruh kombinasi mikoriza dan pupuk kandang kambing terhadap penyakit bercak daun, keriting daun dan infeksi mikoriza

\begin{tabular}{|c|c|c|c|}
\hline \multirow[b]{2}{*}{$\begin{array}{l}\text { Perla } \\
\text { kuan }\end{array}$} & \multicolumn{3}{|c|}{ Variabel Pengamatan } \\
\hline & $\begin{array}{c}\text { Intensitas } \\
\text { penyakit } \\
\text { Bercak daun }\end{array}$ & $\begin{array}{c}\text { Kejadian } \\
\text { penyakit } \\
\text { keriting daun }\end{array}$ & $\begin{array}{c}\text { Derajat } \\
\text { Infeksi } \\
\text { mikoriza }\end{array}$ \\
\hline MOP0 & $18.89 \mathrm{ab}$ & $7.72 \mathrm{~h}$ & 4.05 \\
\hline M0P1 & $18.33 \mathrm{ab}$ & 18.26 & 4.05 \\
\hline M0P2 & $18.33 \mathrm{ab}$ & $21.30 \mathrm{cdef}$ & 4.05 \\
\hline M0P3 & $18.89 \mathrm{ab}$ & 14.24 & 4.05 \\
\hline M1P0 & $17.78 \mathrm{abc}$ & 27.93 & 55.20 \\
\hline M1P1 & $20.56 \quad$ a & 18.97 efg & 57.32 \\
\hline M1P2 & $15.00 \mathrm{bc}$ & $25.77 \mathrm{abcd}$ & 58.33 \\
\hline M1P3 & $13.89 \mathrm{c}$ & $28.55 \quad a b$ & 60.45 \\
\hline $\mathrm{M} 2 \mathrm{P} 0$ & $18.89 \mathrm{ab}$ & $26.74 \quad a b c$ & 58.69 \\
\hline $\mathrm{M} 2 \mathrm{P} 1$ & $19.44 \quad \mathrm{a}$ & 31.44 & 58.69 \\
\hline $\mathrm{M} 2 \mathrm{P} 2$ & $20.00 \quad \mathrm{a}$ & $27.93 \quad a b$ & 57.32 \\
\hline $\mathrm{M} 2 \mathrm{P} 3$ & $18.89 \mathrm{ab}$ & 24.28 bcde & 57.21 \\
\hline M3P0 & $18.89 \mathrm{ab}$ & $21.75 \mathrm{cdef}$ & 57.32 \\
\hline M3P1 & $17.78 \mathrm{abc}$ & $5.89 \mathrm{~h}$ & 58.69 \\
\hline M3P2 & $17.78 \mathrm{abc}$ & $20.86 \mathrm{def}$ & 57.32 \\
\hline M3P3 & $20.56 \quad$ a & $17.90 \quad \mathrm{fg}$ & 57.32 \\
\hline & $*$ & ** & tn \\
\hline
\end{tabular}

Keterangan: Angka yang diikuti huruf yang sama pada kolom yang sama, tidak berbeda nyata pada Uji Rentang Ganda Duncan (DMRT) taraf 5\%

Data analisis tanah yang dilakukan di Laboratorium Agronomi dan Hortikultura IPB, menunjukkan kadar $\mathrm{pH} \quad \mathrm{H}_{2} \mathrm{O}$ tanah sebelum perlakuan 6.31 yang tergolong $\mathrm{pH}$ agak masam. Kadar P tersedia antara 5-10 ppm (rendah), 11-15 ppm (sedang), 16-20 ppm (tinggi) dan $>20 \mathrm{ppm}$ (sangat tinggi). Hasil kadar P tersedia yang diukur dengan metode Olsen menunjukan nilai 124.25 ppm $\mathrm{P}_{2} \mathrm{O}_{5}$, sehingga kadar $\mathrm{P}$ pada tanah sebelum perlakuan tergolong sangat tinggi. Hal ini memperkuat dugaan bahwa kadar $\mathrm{P}$ tanah sudah tinggi sehingga kombinasi perlakuan mikoriza dan pupuk tidak menguntungkan bagi tanaman, sebaliknya menyebabkan tanaman tanaman menjadi lebih rentan terhadap patogen. Menurut $\mathrm{Qu}$ dkk (2021), mikoriza pada kadar $\mathrm{P}$ tanah tinggi menyebabkan biomassa tanaman rendah dan juga menurunkan ketahanan tanaman.

Tabel 4. Hasil analisis tanah sebelum diberi perlakuan

\begin{tabular}{|c|c|c|}
\hline Parameter & Nilai & Metode \\
\hline $\mathrm{P}$ tersedia & $\begin{array}{c}124.25 \\
\left(\mathrm{ppm} \mathrm{P}_{2} \mathrm{O}_{5}\right)\end{array}$ & $\begin{array}{l}\text { IKLab-50-137,Olsen, } \\
\text { Spektrofotometer UV-VIS }\end{array}$ \\
\hline $\mathrm{pH} \mathrm{H} \mathrm{H}_{2} \mathrm{O}$ & 6.31 & $\begin{array}{l}\text { IKLab-42-129, 1:5, pH } \\
\text { meter }\end{array}$ \\
\hline
\end{tabular}

Mikoriza merupakan mikroba tanah yang mempunyai peran penting dalam penyerapan hara seperti fosfat, air dan juga nutrisi lainnya. Akar yang terinfeksi dengan mikoriza mempunyai eksudat yang berbeda, eksudat ini dapat meningkatkan ketahanan tanaman karena senyawa tertentu yang dihasilkan mikoriza. Namun, karena eksudat tersebut dihasilkan di area perakaran maka hanya menekan patogen tular tanah tertentu seperti Phytophtora, Phytium, Fusarium serta Rhizoctonia (Talanca, 2010). Selain itu, Solihah, dkk. (2013) melaporkan bahwa mikoriza campuran yang terdiri atas Gigaspora sp., Glomus sp., dan Acaulospora sp. dapat menekan intensitas dan memperpanjang masa inkubasi penyakit layu Fusarium pada tanaman semangka dan juga pada tomat yang dilaporkan Hasanah, dkk. (2017). Hal ini diduga mendasari lebih efektifnya mikoriza menekan patogen tular tanah dibandingkan dengan patogen yang menyerang bagian tajuk tanaman seperti virus.

\section{KESIMPULAN}

Berdasarkan hasil penelitian, terdapat dua jenis gejala penyakit yang terjadi pada tanaman ciplukan yaitu gejala bercak daun yang disebabkan Cercospora sp. dan gejala keriting daun yang disebabkan Cucumber Mozaik Virus (CMV). Kombinasi perlakuan mikoriza dan pupuk organik (pupuk kandang) cenderung meningkatkan intensitas penyakit bercak daun dan kejadian penyakit keriting daun. Aplikasi mikoriza dan pupuk organik sebaiknya dilakukan pada lahan yang mempunyai kadar $\mathrm{P}$ tersedia rendah sehingga simbiosis antara tanaman dengan mikoriza mempunyai pengaruh yang baik.

\section{UCAPAN TERIMA KASIH}

Ucapan terima kasih disampaikan kepada Direktorat Riset dan Pengabdian Masyarakat Dirjen Penguatan Riset dan Pengembangan Kemenristek Dikti, yang telah membiayai penelitian ini melalui skim Penelitian Dosen Pemula tahun 2020, Rektor, Ketua LPPM, Dekan Sains dan Teknologi UNU Purwokerto yang telah memberikan izin, kesempatan dan arahan dalam penelitian ini.

\section{DAFTAR PUSTAKA}

Ariati A.C, Marisa CO, Edenes MSL, Marco AB, Chaiane RG, C. O. 2017. Effects of mineral and organic nitrogen on chemical characteristics of Physalis fruits. Journal of Agronomy, 16 (2), pp. 94-100. doi: 10.3923/ja.2017.94.100.

Balzergue C, Chabaud M, Barker DG, Bécard G, R. S. 2013. High phosphate reduces host ability to develop arbuscular mycorrhizal symbiosis without affecting root calcium spiking responses to the fungus. Frontiers in Plant Science. 4, p. 426 doi: 10.3389/fpls.2013.00426. 
Fitriani, M. L., Wiyono, S. dan Sinaga, M. S. .2019. Potensi Kolonisasi Mikoriza Arbuskular dan Cendawan Endofit dan Kemampuannya dalam Pengendalian Layu Fusarium pada Bawang Merah Colonization Potential of Arbuscular Mycorrhiza and Endophytic Fungi and Its Effectiveness in Control Fusarium Wilt on Shallot. Jurnal Fitopatologi Indonesia. 15 (November), pp. 228-238. doi: 10.14692/jfi.15.6.

Guimarães, E.T., Milena S. Lima, Luana A. Santos, Ivone $M$. Ribeiro, Therezinha B. C. Tomassini, Ricardo Ribeiro dos Santos, Washington L. C. dos Santos dan Milena B. P. Soares. 2009. Activity of physalins purified from Physalis angulata in in vitro and in vivo models of cutaneous leishmaniasis. Journal of Antimicrobial Chemotherapy. 64(1), pp. 84-87. doi: 10.1093/jac/dkp170.

Hasanah, U., Purnomowati dan Dwiputranto, U. 2017. Pengaruh Inokulasi Mikoriza Vesikula Arbuskula (MVA) Campuran Terhadap Kemunculan Penyakit Layu Fusarium pada Tanaman Tomat (Solanum lycopersicum). Scripta Biologica, 4(1), pp. 31-35.

Hernandez, Andrea I Raya, Pablo FJL, Dante ALC, Tsiri D, Jose ACV, John L. 2020. Field evidence for maize-mycorrhiza interactions in agroecosystems with low and high $\mathrm{P}$ soils under mineral and organic fertilization. Appl. Soil Ecol, 149. https://doi.org/10.1016/j.apsoil.2020.103511

Ishaq L, Adu Tae ASJ, Airthur MA, Bako PO. 2021. Effect of single and mixed inoculation of arbuscular mycorrhizal fungi and phosphorus fertilizer application on corn growth in calcareous soil. Biodiversitas, 22 (4), pp.1920-1926. https://doi.org/10.13057/biodiv/d220439.

Januário, A.H., Rodrigues Filho.E, Pietro R.C.L.R, S. Kashima .S, Sato D.N, França S.C. 2002. Antimycobacterial physalins from Physalis angulata L. (Solanaceae). Phytotherapy Research, 16 (5), pp. 445-448. doi: 10.1002/ptr.939.

Sastry K. Subramanya, Bikash Mandal, John Hammond, S. W. Scott, R. W. B. 2019. Encyclopedia of Plant Viruses and Viroids. 2019th edn. New Delhi: Springer. doi: doi.org/10.1007/978-81-322-3912-3_704.

Mochizuki, T. dan Ohki, S. T. 2012. Cucumber mosaic virus: Viral genes as virulence determinants. Molecular Plant Pathology,
13(3), pp. 217-225. doi: 10.1111/j.13643703.2011.00749.x.

Nurvitha, L. 2016. Pengaruh Abu Dan Pupu Kandang Terhadap Pertumbuhan Dan Hasil Tanaman Ciplukan (Physalis angulata L.) Pada Media Gambut. Agrovigor, 9(1), pp. 33-41. doi: https://doi.org/10.21107/agrovigor.v9i1.1523

Oktaviana, G. dan Harso, W. 2019. Pupuk P Yang Berbeda Terhadap Serapan $P$ Dan Pertumbuhan Tanaman Jagung ( Zea mays L .). Biocelebes, 13(2), pp. 142-151.

Osho, A., Adetunji, T., Fayemi S. O. dan Moronkola, D.O. 2010. Antimicrobial activity of essential oils of Physalis angulata L. African Journal of Traditional Complementary Alternative Medicines, 7(4), pp. 303-306. doi: 10.4314/ajtcam.v7i4.56696.

Pandawani, N. P., Hanum, F. 2016. Inang Alternatif Cucumber Mosaic Virus (CMV) Penyebab Penyakit Mosaik pada Tanaman Mentimun. Prosiding Semnas Hasil ..., (11), pp. 622629. Available at: http://jurnal.unmas.ac.id/index.php/pros/articl e/view/352.

Park, T. S., Choi, G. S. dan Hong, J. S. 2016. Characterization of Cucumber mosaic virus Isolated from Trifolium repens in Korea. Research in Plant Disease, 22(1), pp. 55-58. doi: 10.5423/rpd.2016.22.1.55.

Phengsintham, P. 2013. Monograph of Cercosporoid fungi from Laos. Current Research in Environmental \& Applied Mycology, 3(1), pp. 34-158. doi: $10.5943 /$ cream/3/1/2.

Pulungan, A. S. S. 2015. Biodiversity of FMA in red pepper rhizosfer. Jurnal Biosains, 1(3), pp. 125-129. doi: https://doi.org/10.24114/jbio.v1i3.2933.

Qin, Zefeng, Hongyan Z, Gu F, Peter C, Junling Z, Xiaolin L, Jingping G. 2020. Soil phosphorus availability modifies the relationship between AM fungal diversity and mycorrhizal benefits to maize in an agricultural soil. Soil Biol. Biochem, 144. https://doi.org/10.1016/j.soilbio.2020.107790

Qu, Laiye, Minggang Wang, Arjen Biere. 2021. Interactive Effects of Mycorrhizae, Soil Phosphorus, and Light on Growth and Induction and Priming of Defense in Plantago lanceolata. Front. Plant Sci, 12, 
pp.

1-20.

https://doi.org/10.3389/fpls.2021.647372

Rengifo-Salgado, E. dan Vargas-Arana, G. 2013. Physalis angulata L. (Bolsa mullaca): A review of its traditional uses, chemistry and pharmacology. Boletin Latinoamericano y del Caribe de Plantas Medicinales y Aromaticas, 12(5), pp. 431-445.

Sariasih, Y., Hadisutrisno, B. dan Widada, J. 2012. Pengaruh Fungi Mikoriza Arbuskular Dalam Medium Zeolit Terhadap Pertumbuhan dan Intensitas Penyakit Bercak Daun Pada Bibit Kakao. Jurnal Agroteknologi Tropika, 1(1), pp. 1-7. Available at: https://jatt.ejournal.unri.ac.id/index.php/JAT T/article/view/1188.

Sasli, I. dan Wicaksono, A. 2017. Domestikasi Tumbuhan Potensi Obat Ciplukan ( Physalis angulata L .) dengan Aplikasi Mikoriza Arbuskula dan Pupuk NPK. Jurnal Kesehatan Khatulistiwa, 3(2), pp. 512-523. Available at: https://jurnal.untan.ac.id/index.php/jfk/article /view/32177.

Solihah, S., Dwiputranto, U. dan Purnomowati. 2013. Inokulasi Mikoriza Vesikula Arbuskula (Mva) Campuran Sebagai Pengendali Penyakit Layu Fusarium Pada Tanaman Semangka (Citrullus vulgaris Schard). Agritech, 15, pp. 1-11. doi: 10.30595/agritech.v15i1.995.

Talanca, H. 2010. Status Cendawan Mikoriza Vesikular-Arbuskular ( MVA ) pada Tanaman. Prosiding Pekan Serealia Nasional, pp. 978-979.

Travlos, I. S. 2012. Invasiveness of Cut-Leaf Ground-Cherry (Physalis angulata L.) Populations and Impact of Soil Water and Nutrient Availability. Chilean journal of agricultural research, 72(3), pp. 358-363. doi: $10.4067 / \mathrm{s} 0718-58392012000300009$. 